\title{
EFEKTIFITAS PENGGUNAAN METODE DISCOVERY LEARNING TERHADAP HASIL BELAJAR MENULIS KALIMAT BAHASA JEPANG
}

\author{
Megawati Adinda Rizkiningrum ${ }^{1}$, Wilda Liona Suri ${ }^{2}$, Erliyani ${ }^{3}$ \\ ${ }^{1-3}$ Sekolah Pascasarjana, Universitas Muhammadiyah Prof. Dr. Hamka, Indonesia
}

DOI: 10.23917/humaniora.v20i2.9751

Submit: 2 Januari 2020. Revisi: 19 Agustus 2020. Diterima: 20 Agustus 2020

Available Online: 29 Agustus 2020. Periode Terbit: Agustus 2020

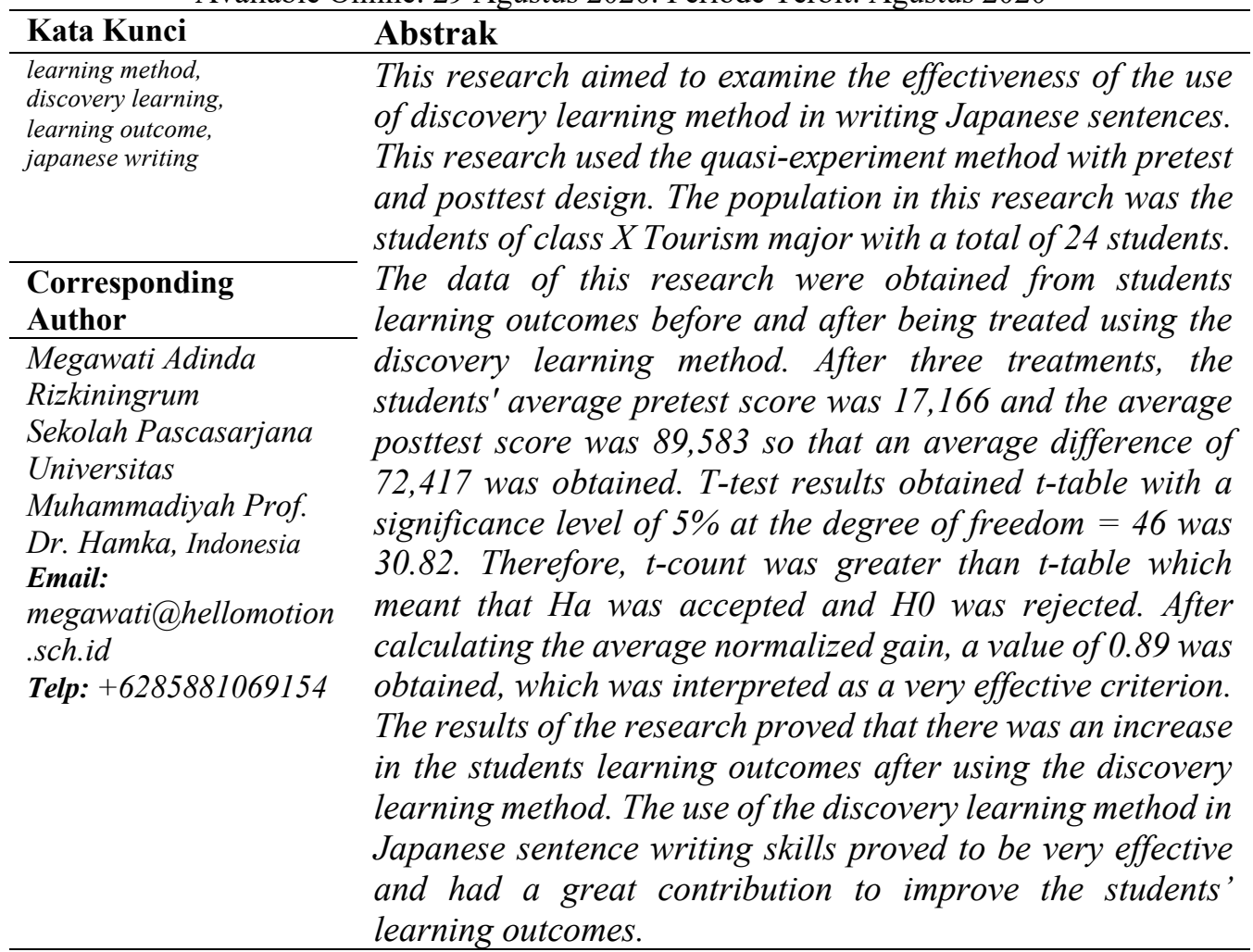

\section{PENDAHULUAN}

Manusia sebagai makhluk sosial berkomunikasi dengan sesama menggunakan Bahasa. Bahasa adalah sistem simbol bunyi yang memiliki makna dan dihasilkan alat ucap manusia untuk menghasilkan pemikiran manusia (Wibowo, 2001). Dengan bahasa seseorang dapat menyampaikan gagasan yang ada di dalam pikirannya. Kegiatan komunikasi dapat berlangsung secara lisan dengan suara dan dapat pula berlangsung secara tertulis menggunakan huruf. Kegiatan komunikasi dengan bahasa terwujud dalam empat aspek keterampilan, yakni keterampilan menyimak atau mendengarkan atau kiku noury$o k u$ (聞く能力), keterampilan berbicara atau hanasu nouryoku (話す能力), keterampilan membaca atau yomu nouryoku (読む能力) dan keterampilan menulis atau kaku nouryoku (書く能力) (Danasasmita, 2009). 
Menulis merupakan kegiatan menyampaikan suatu ide atau gagasan melalui bentuk tulisan. Dalam menyampaikan ide atau gagasan, umumnya ditulis ke dalam bentuk kalimat sehingga seseorang akan lebih mudah memahami gagasan yang akan disampaikan.

Jepang merupakan salah satu negara yang memiliki keunikan dalam struktur kalimat serta huruf yang digunkan dalam menulis kalimat. Huruf dalam bahasa Jepang disebut moji, termasuk di dalamnya yaitu huruf-huruf kanji, huruf hiragana, huruf katakana, dan huruf romaji (Sudjianto \& Dahidi, 2004).

Dalam proses pembelajaran Bahasa Jepang terdapat perbedaan antara struktur kalimat dalam Bahasa Indonesia dengan struktur kalimat dalam Bahasa Jepang. Struktur kalimat dalam Bahasa Indonesia terdiri dari subjek, predikat, objek, dan keterangan. Adapun struktur kalimat dalam Bahasa Jepang terdiri dari subjek, keterangan, objek, dan predikat. Pada awal kegiatan belajar Bahasa Jepang siswa umumnya merangkai kosakata menjadi kalimat sederhana dengan menggunakan huruf hiragana. Huruf hiragana diajarkan dengan tujuan agar siswa dapat menulis kalimat sederhana dalam Bahasa Jepang. Akan tetapi, mempelajari Bahasa Jepang merupakan hal yang sulit dikarenakan struktur kalimat yang berbeda dengan Bahasa Indonesia menyebabkan siswa menjadi kebingungan dalam menulis kalimat Bahasa Jepang.

Berdasarkan pengamatan yang dilakukan peneliti pada Program Kegiatan Mengajar (PKM) mata pelajaran Bahasa Jepang di kelas X jurusan Pariwisata SMK Jaya Wisata 2 Jakarta, peneliti menemukan indikasi permasalahan dimana siswa cenderung tidak bisa membuat kalimat Bahasa Jepang dengan menggunakan huruf hiragana sehingga hasil belajarnya kurang maksimal. Hal tersebut dapat dilihat dari nilai Ujian Tengah Semester pada mata pelajaran Bahasa Jepang yang tidak mencapai KKM. Dalam proses pembelajaran banyak faktor yang mempengaruhi hasil belajar. Salah satunya adalah penggunaan metode yang tidak tepat. Pengajar sering kali menggunakan metode ceramah dalam menyampaikan materi. Hal ini menyebabkan Kegiatan Belajar Mengajar (KBM) di kelas menjadi membosankan sehingga dibutuhkan metode yang membuat siswa lebih aktif dalam kegiatan KBM.

Berdasarakan permasalahan yang telah diuraikan di atas, peneliti melakukan perbaikan dengan salah satu metode pembelajaran efektif yang dinamakan metode discovery learning. Model pembelajaran discovery learning (model pembelajaran penemuan) adalah model pembelajaran yang menghendaki para siswa untuk mengkonstruksi pengetahuan mereka sendiri (Yang, Liao, Ching, Chang, \& Chan, 2010), berdasarkan pengalaman masa lalu mereka dan pengetahuan yang mereka miliki saat ini untuk mengeksplorasi dan memahami konsep-konsep (Waterman, 2013) dalam lingkungan pembelajaran yang eksploratif (Balim, 2009). Model pembelajaran ini berorientasi pada aktivitas belajar dan melibatkan demostrasi praktis, diskusi, dan eksperimen dimana selama proses pembelajaran para siswa menggunakan cara belajar yang scientific seperti adanya observasi, klasifikasi, investigasi dan interprestasi yang kritis terhadap apa yang mereka temukan (Akanbi \& Kolawole, 2014). Melalui proses tersebut, siswa difasilitasi agar dapat menemukan konsep-konsep dan prinsip-prinsip melalui proses mentalnya sendiri (Rahman \& Maarif, 2014).

Tujuan utama dari model pembelajaran ini adalah untuk meningkatkan daya pikir, membangun motivasi dari dalam dan luar, belajar caranya menemukan, dan mengembangkan pemikiran (Bruner, 1961, dalam Tran, Nguyen, Bui, \& Phan, 2014). Dalam model pembelajaran ini peserta didik dituntun untuk mengembangkan kreativitas, mendapatkan pengalaman langsung dalam belajar, mengembangkan kemampuan berpikir rasional dan kritis, meningkatkan keaktifan dalam proses pembelajaran, belajar memecahkan masalah, dan mendapatkan inovasi dalam proses pembelajaran (Illahi, 2012).

Beberapa penelitian mengenai penggunaan model pembelajaran discovery learning telah dilakukan oleh beberapa peneliti dengan hasil yang memuaskan diantaranya penelitian yang dilakukan oleh Farhatani (2014) yang meneliti "Peningkatan Kompetensi Mata Pelajaran Dasar dan Pengukuran Listrik Siswa Kelas X Program Keahlian Teknik 
Instalasi Tenaga Listrik di SMK Muhammadiyah 1 Klaten Utara dengan Metode Discovery Learning." Penelitian ini merupakan penelitian tindakan kelas yang hasil penelitian menunjukkan bahwa penerapan metode discovery learning dapat meningkatkan hasil aspek kognitif siswa dari nilai rata-rata 76,36 menjadi 80,78 . Sementara itu, pada aspek afektif terjadi peningkatan pada siklus I sebesar $46,68 \%$ dan $54,98 \%$, sedangkan pada siklus II sebesar $71,09 \%$ dan $75,29 \%$. Berdasarkan penelitian yang telah dilakukan, diketahui bahwa dengan penerapan model pembelajaran Discovery Learning dinilai dapat meningkatkan hasil belajar dari siswa Kelas X SMK Muhammadiyah 1 Klaten Utara.

\section{METODE}

Penelitian ini dilakukan di SMK Jaya Wisata 2 Jakarta. Subjek yang diteliti adalah siswa kelas X Pariwisata yang merupakan kelas eksperimen. Penelitian ini berlangsung dari bulan Oktober sampai dengan Desember 2016 dengan diawali pra-survei pada bulan Agustus 2016. Peneliti menggunakan pendekatan kuantitatif. Metode yang digunakan pada penelitian ini adalah quasi experiment yaitu penelitian tanpa adanya kelas pembanding atau kelas kontrol dengan pola one-group pretest-posttest design. Adapun gambaran mengenai rancangan tersebut adalah sebagai berikut:

$$
\mathrm{O}_{1} \mathrm{X} \mathrm{O}_{2}
$$

Keterangan:

$\mathrm{O}_{1} \quad$ : Pengukuran kemampuan awal kelompok eksperimen

$\mathrm{O}_{2} \quad$ : Pengukuran kemampuan akhir kelompok eksperimen

$\mathrm{X} \quad$ : Pemberian perlakuan

Teknik sampling yang digunakan dalam penelitian ini yaitu teknik total sampling atau disebut juga dengan sampel jenuh. Populasi dan sampel diambil dari siswa kelas $\mathrm{X}$ Pariwisata yang jumlahnya 24 orang. Penelitian ini menggunakan dua variabel yang terdiri dari variabel bebas (independent) dan terikat (dependent). Variabel bebas adalah variabel yang mempengaruhi atau yang menjadi sebab perubahan atau timbulnya variabel dependen (terikat). Variabel bebas pada penelitian ini adalah penggunaan metode discovery learning. Adapun variabel terikat adalah variabel yang dipengaruhi atau yang menjadi akibat karena adanya variabel bebas. Variabel terikat pada penelitian ini adalah keterampilan menulis kalimat menggunakan huruf hiragana.

Adapun pengumpulan data dari penelitian ini dilakukan dengan cara:

\section{Tes}

Tes yang dilakukan dalam penelitian ini berupa pretest dan posttest yang diberikan di kelas eksperimen untuk mengetahui rentang nilai dan efektivitas perbandingan hasil belajar kelas eksperimen setelah diterapkannya metode discovery learning. Tes yang diujikan berupa penguasaan keterampilan menulis kalimat menggunakan huruf hiragana. Terdapat 20 butir soal dan dibagi menjadi 4 bagian dalam bentuk soal bergambar, mengubah ke bentuk negatif dan soal acak.

Pengolahan data menggunakan tahapan sebagai berikut: mencari rata-rata (mean) dari kedua variabel, standar deviasi dari kedua variabel, standar error mean dari kedua variabel, standar error perbedaan antara kedua variabel, mencari t-hitung, dan menguji hipotesis. Pengujian hipotesis pada penelitian ini adalah dengan:

$h_{k} \quad$ : terdapat perbedaan signifikan antara variabel $X$ dan variabel $Y$

$\mathrm{h}_{\mathrm{o}} \quad$ : tidak terdapat perbedaan signifikan antara variabel $\mathrm{X}$ dan variabel $\mathrm{Y}$

Kebenaran dua hipotesis tersebut diuji dengan cara membandingkan $t_{\text {hitung }}$ dengan $t_{\text {tabel }}$ dengan terlebih dahulu menetapkan derajat kebebasan. Apabila $t_{\text {hitung }}$ lebih kecil atau sama dengan $t_{\text {tabel }}\left(t_{\text {hitung }} \leq t_{\text {tabel }}\right)$ maka Ho diterima dan Hk ditolak, dengan kata lain tidak ada pengaruh yang signifikan antara variabel $\mathrm{X}$ dan variabel $\mathrm{Y}$. Apabila nilai $\mathrm{t}_{\text {hitung }}$ lebih besar dari nilai $t_{\text {tabel }}\left(t_{\text {hitung }} \geq t_{\text {tabel }}\right)$ maka Ho ditolak dan Hk diterima, dengan kata lain 
terdapat perbedaan yang cukup signifikan antara variabel $\mathrm{X}$ dan variabel $\mathrm{Y}$. Sementara itu untuk mengetahui nilai efektivitas pembelajaran dilakukan perhitungan normalized gain.

Tabel 1. Kriteria Efektivitas

\begin{tabular}{cc}
\hline Interval Normalized Gain & Kriteria \\
\hline $0,01-0,40$ & Kurang efektif \\
$0,41-0,70$ & Efektif \\
$0,71-1,00$ & Sangat efektif \\
\hline
\end{tabular}

\section{Angket}

Angket yang digunakan dalam penelitian ini adalah jenis angket langsung yang tertutup. Hasil angket diolah dengan cara melakukan skoring dan tabulasi data. Hasil tersebut kemudian diinterpretasikan sesuai tabel 2 berikut:

Tabel 2. Penafsiran Data Angket

\begin{tabular}{cc}
\hline Persentase & Jumlah Responden \\
\hline $0 \%$ & tidak ada seorang pun \\
$1 \%-5 \%$ & hampir tidak ada \\
$6 \%-25 \%$ & sebagian kecil \\
$26 \%-49 \%$ & hampir setengahnya \\
$50 \%$ & setengahnya \\
$51 \%-75 \%$ & lebih dari setengah \\
$76 \%-95 \%$ & sebagian besar \\
$96 \%-99 \%$ & hampir seluruhnya \\
$100 \%$ & seluruhnya \\
\hline
\end{tabular}

(Sumber: Arikunto, 2006)

\section{HASIL}

Berdasarkan hasil penelitian diketahui bahwa dari 24 orang siswa diproleh rata-rata pre-test sebesar 17.16667 dengan nilai terendah 0 dan tertinggi 40. Sementara dari posttest diperoleh nilai rata-rata 89.58333 , dengan nilai terendah 76 dan tertinggi 98 . Berikut ini adalah tabel pengolahan nilai pre-test dan post-test.

Tabel 3. Pengolahan Data Pre-test dan Post-test

\begin{tabular}{ccccccc}
\hline Nama & $\mathbf{X}$ & $\mathbf{Y}$ & $\mathbf{X}$ & $\mathbf{Y}$ & $\mathbf{X}^{\mathbf{2}}$ & $\mathbf{Y}^{\mathbf{2}}$ \\
\hline $\mathrm{A}$ & 89 & 9 & -0.58333 & -8.16667 & 0.340278 & 66.69444 \\
$\mathrm{~B}$ & 90 & 11 & 0.416667 & -6.16667 & 0.173611 & 38.02778 \\
$\mathrm{C}$ & 86 & 0 & -3.58333 & -17.1667 & 12.84028 & 294.6944 \\
$\mathrm{D}$ & 81 & 18 & -8.58333 & 0.833333 & 73.67361 & 0.694444 \\
E & 89 & 28 & -0.58333 & 10.83333 & 0.340278 & 117.3611 \\
F & 76 & 40 & -13.5833 & 22.83333 & 184.5069 & 521.3611 \\
G & 85 & 14 & -4.58333 & -3.16667 & 21.00694 & 10.02778 \\
H & 98 & 11 & 8.416667 & -6.16667 & 70.84028 & 38.02778 \\
I & 90 & 4 & 0.416667 & -13.1667 & 0.173611 & 173.3611 \\
J & 95 & 17 & 5.416667 & -0.16667 & 29.34028 & 0.027778 \\
K & 89 & 13 & -0.58333 & -4.16667 & 0.340278 & 17.36111 \\
L & 84 & 17 & -5.58333 & -0.16667 & 31.17361 & 0.027778 \\
M & 88 & 15 & -1.58333 & -2.16667 & 2.506944 & 4.694444 \\
N & 85 & 36 & -4.58333 & 18.83333 & 21.00694 & 354.6944 \\
O & 90 & 25 & 0.416667 & 7.833333 & 0.173611 & 61.36111 \\
P & 92 & 11 & 2.416667 & -616667 & 5.840278 & 38.02778 \\
Q & 96 & 29 & 6.416667 & 11.83333 & 41.17361 & 140.0278 \\
R & 85 & 30 & -4.58333 & 12.83333 & 21.00694 & 164.6944 \\
\hline
\end{tabular}




\begin{tabular}{cllcccc}
\hline Nama & $\mathbf{X}$ & $\mathbf{Y}$ & $\mathbf{X}$ & $\mathbf{Y}$ & $\mathbf{X}^{2}$ & $\mathbf{Y}^{\mathbf{2}}$ \\
\hline $\mathrm{S}$ & 95 & 4 & 5.416667 & -13.1667 & 29.34028 & 173.3611 \\
$\mathrm{~T}$ & 90 & 13 & 0.416667 & -4.16667 & 0.173611 & 17.36111 \\
$\mathrm{U}$ & 98 & 12 & 8.416667 & -5.16667 & 70.84028 & 26.69444 \\
$\mathrm{~V}$ & 98 & 26 & 8.416667 & 8.833333 & 70.84028 & 78.02778 \\
$\mathrm{~W}$ & 89 & 16 & -0.58333 & -1.16667 & 0.340278 & 1.361111 \\
$\mathrm{X}$ & 92 & 13 & 2.416667 & -4.16667 & 5.840278 & 17.36111 \\
2150 & 412 & & \multicolumn{3}{c}{693.8333} & 2355.333 \\
89.58333 & 17.16667 & & \multicolumn{3}{c}{} \\
\hline
\end{tabular}

Keterangan:

$\mathrm{X} \quad$ : nilai post-test

Y : nilai pre-test

Tabel 4. Hasil Data Pre-test dan Post-test

\begin{tabular}{lll}
\hline & Post-test & Pre-test \\
\hline Mean & 89,58 & 17,16 \\
Standar Deviasi & 5,376 & 9,906 \\
Standar Error & 1,12 & 2,06 \\
SEM $_{\mathrm{xy}}$ & 2,35 & \\
\hline
\end{tabular}

Hasil analisis efektivitas pembelajaran dapat diketahui dari perhitungan nilai g seperti tercantum dalam tabel 5 berikut ini:

Tabel 5. Data Normalized Gain

\begin{tabular}{cccc}
\hline Nama & Pre-test & Post-test & gain \\
\hline A & 9 & 89 & 0.898876 \\
B & 11 & 90 & 0.908046 \\
C & 0 & 86 & 0.877551 \\
D & 18 & 81 & 0.7875 \\
E & 28 & 89 & 0.871429 \\
F & 40 & 76 & 0.62069 \\
G & 14 & 85 & 0.845238 \\
H & 11 & 98 & 1 \\
I & 4 & 90 & 0.914894 \\
J & 17 & 95 & 0.962963 \\
K & 13 & 89 & 0.894118 \\
L & 17 & 84 & 0.82716 \\
M & 15 & 88 & 0.879518 \\
N & 36 & 85 & 0.790323 \\
O & 25 & 90 & 0.890411 \\
P & 11 & 92 & 0.931034 \\
Q & 29 & 96 & 0.971014 \\
R & 30 & 85 & 0.808824 \\
S & 4 & 95 & 0.968085 \\
T & 13 & 90 & 0.905882 \\
U & 12 & 98 & 1 \\
V & 26 & 98 & 1 \\
W & 16 & 89 & 0.890244 \\
X & 13 & 92 & 0.929412 \\
& 412 & 2150 & 21.37321 \\
& 17.16667 & 89.58333 & 0.89055 \\
\hline
\end{tabular}


Tabel 6. Data Normalized Gain

\begin{tabular}{ll}
\hline Nilai Gain & 21,37 \\
\hline Normalized Gain & 0,89 \\
\hline
\end{tabular}

Data angket diolah dengan cara menghitung persentase tiap jawaban dari setiap nomor. Berikut adalah interpretasi pengolahan data angket:

Tabel 7. Penafsiran Data Angket

\begin{tabular}{|c|c|c|c|}
\hline & Jawaban & $\mathrm{F}$ & Presentase \\
\hline \multirow{3}{*}{$\begin{array}{l}\text { Siswa menyukai pembelajaran bahasa Jepang } \\
\text { dengan menggunakan metode discovery } \\
\text { learning. }\end{array}$} & $\mathrm{Ya}$ & 24 & $100 \%$ \\
\hline & Tidak & 0 & $0 \%$ \\
\hline & Jumlah & 24 & $100 \%$ \\
\hline \multirow{3}{*}{$\begin{array}{l}\text { Metode pembelajaran discovery learning } \\
\text { dapat memotivasi belajar siswa terutama } \\
\text { dalam keterampilan menulis bahasa Jepang } \\
\text { menggunakan huruf hiragana. }\end{array}$} & $\mathrm{Ya}$ & 24 & $100 \%$ \\
\hline & Tidak & 0 & $0 \%$ \\
\hline & Jumlah & 24 & $100 \%$ \\
\hline \multirow{3}{*}{$\begin{array}{l}\text { Dengan metode pembelajaran discovery } \\
\text { learning siswa lebih mudah belajar bahasa } \\
\text { Jepang. }\end{array}$} & $\mathrm{Ya}$ & 22 & $92 \%$ \\
\hline & Tidak & 2 & $8 \%$ \\
\hline & Jumlah & 24 & $100 \%$ \\
\hline \multirow{3}{*}{$\begin{array}{l}\text { Penggunaan metode pembelajaran discovery } \\
\text { learning dalam pembelajaran bahasa Jepang } \\
\text { menjadi menyenangkan. }\end{array}$} & $\mathrm{Ya}$ & 24 & $100 \%$ \\
\hline & Tidak & 0 & $0 \%$ \\
\hline & Jumlah & 24 & $100 \%$ \\
\hline \multirow{3}{*}{$\begin{array}{l}\text { Metode pembelajaran discovery learning } \\
\text { dapat menumbuhkan rasa ingin tahu siswa } \\
\text { terhadap materi yang dipelajari. }\end{array}$} & $\mathrm{Ya}$ & 22 & $92 \%$ \\
\hline & Tidak & 2 & $8 \%$ \\
\hline & Jumlah & 24 & $100 \%$ \\
\hline \multirow{3}{*}{$\begin{array}{l}\text { Dengan menggunakan discovery learning } \\
\text { membuat metode pembelajaran menjadi lebih } \\
\text { variatif. }\end{array}$} & $\mathrm{Ya}$ & 24 & $100 \%$ \\
\hline & Tidak & 0 & $0 \%$ \\
\hline & Jumlah & 24 & $100 \%$ \\
\hline \multirow{3}{*}{$\begin{array}{l}\text { Metode pembelajaran discovery learning } \\
\text { membuat siswa aktif dalam proses } \\
\text { pembelajaran terutama dalam kegiatan } \\
\text { menulis. }\end{array}$} & $\mathrm{Ya}$ & 22 & $92 \%$ \\
\hline & Tidak & 2 & $8 \%$ \\
\hline & Jumlah & 24 & $100 \%$ \\
\hline \multirow{3}{*}{$\begin{array}{l}\text { Penggunaan metode pembelajaran discovery } \\
\text { learning berpengaruh terhadap hasil belajar } \\
\text { siswa terutama dalam kegiatan menulis. }\end{array}$} & $\mathrm{Ya}$ & 24 & $100 \%$ \\
\hline & Tidak & 0 & $0 \%$ \\
\hline & Jumlah & 24 & $100 \%$ \\
\hline
\end{tabular}

\section{PEMBAHASAN}

Berdasarkan data yang ada pada tabel 3. dan 4., didapat nilai thitung sebesar 30,82 dan derajat kebebasan $(\mathrm{db})$ sebesar 46. Dengan db sebesar 46, maka pada taraf signifikasi $5 \% t_{\text {tabel }}$ adalah 2,01290. Kemudian jika dibandingkan dengan $t_{\text {hitung }}$ sebesar 30,82 berarti $t_{\text {hitung }}$ lebih besar daripada $t_{\text {tabel }}\left(t_{\text {hitung }}>t_{\text {tabel }}\right)$ sehingga Hk diterima dan Ho ditolak. Dapat disimpulkan bahwa metode pembelajaran discovery learning untuk pembelajaran menulis kalimat dengan huruf hiragana pada pelajaran bahasa Jepang terbukti efektif. Hal ini sesuai dengan penelitian yang dilakukan oleh Setiyowati (2019) dengan judul Pengaruh Model Pembelajaran Discovery Learning Menggunakan Video Scribe Sparkol terhadap Hasil Belajar Siswa SMK. Hasil penelitian menunjukkan bahwa signifikansi antara kelompok eksperimen dan kelompok kontrol adalah 0,001. Karena signifikansi $<0,05, \mathrm{H} 0$ ditolak. Maka dengan demikian hipotesis Ha diterima, simpulannya yaitu metode discovery learning berpengaruh terhadap hasil belajar siswa SMK. Pembelajaran metode 
discovery learning membantu siswa memperkuat daya ingat dan mampu memberikan kesempatan siswa untuk berkembang dan maju sesuai dengan kemampuan masing-masing. Penggunaan metode ini bisa membuat suasana kelas menjadi lebih hidup dan siswa menjadi lebih semangat dalam proses pembelajaran.

Sementara itu, dalam penelitian lainnya yang dilakukan oleh Suminar (2016) dengan judul "Pengaruh Model Pembelajaran Discovery Learning dan Problem Based Learning terhadap Prestasi Belajar Peserta Didik" juga didapat hasil yang signifikan. Hasil penelitian menunjukkan bahwa dengan taraf kepercayaan sebesar $95 \%$ atau a $=0,05$ dapat diketahui bahwa hasil thitung $>$ ttabel $=3.187560>1.995468907$ sehingga baik kelas eksperimen yang menggunakan model pembelajaran discovery learning maupun kelas kontrol yang menggunakan model pembelajaran problem based learning (PBL) terdapat perbedaan antara kelas eksperimen dengan kelas kontrol, yaitu sebesar 2,0. Berdasarkan hasil analisis data, perbedaan prestasi belajar antara kelas eksperimen yang menerapkan model pembelajaran discovery learning dengan kelas kontrol yang menerapkan model pembelajaran problem based learning menunjukkan bahwa model pembelajaran discovery learning adalah model pembelajaran yang lebih cocok diterapkan pada mata pelajaran korespondensi di SMK karena dapat meningkatkan prestasi belajar peserta didik pada mata pelajaran tersebut.

Tabel 5. dan 6. menunjukkan bahwa metode pembelajaran discovery learning untuk pembelajaran menulis kalimat dengan huruf hiragana dalam mata pelajaran bahasa Jepang memiliki kriteria sangat efektif dengan nilai gain 21,37 dan rata-rata normalized gain sebesar 0,89. Berdasarkan penelitian yang dilakukan oleh Huurun'ien (2017) dengan judul "Efektivitas Penggunaan E-Learning Berbasis Schoology dengan Menggunakan Model Discovery Learning terhadap Prestasi Belajar Siswa SMK" disimpulkan bahwa penggunaan e-learning berbasis schoology menggunakan model discovery learning lebih efektif, dengan peningkatan nilai gain sebesar 0,94 . Sedangkan pembelajaran konvensional memberikan peningkatan nilai gain sebesar 0,74. Metode discovery learning dalam pelaksanaannya membuat siswa berinteraksi secara langsung antar teman sekelompok, belajar menghargai teman satu sama lain, berani mengambil keputusan, meningkatkan rasa percaya diri siswa dan daya ingat serta dapat meningkatkan kemampuan menulis.

Sementara itu, tabel 7. menunjukkan bahwa sebanyak $8 \%$ siswa menjawab metode ini tidak memberikan kemudahan bagi mereka, tidak dapat menumbuhkan rasa ingin tahu siswa terhadap materi yang dipelajari serta tidak membuat siswa aktif dalam proses pembelajaran terutama dalam kegiatan menulis. Sementara itu, seluruh siswa (100\%) menyukai pembelajaran bahasa Jepang dengan metode discovery learning. Selain itu, mereka juga berpendapat metode ini dapat memotivasi belajar siswa terutama dalam keterampilan menulis bahasa Jepang menggunakan huruf hiragana. Penggunaan metode seperti ini dalam kelas bahasa Jepang membuat suasana belajar menjadi menyenangkan, lebih variatif, dan berpengaruh terhadap hasil belajar siswa terutama dalam kegiatan menulis.

\section{SIMPULAN}

Keefektifan penggunaan metode discovery learning dapat dilihat berdasarkan hasil analisis data yang diperoleh dari nilai rata-rata pretest dan posttest siswa. Nilai rata-rata pretest siswa sebelum menggunakan metode discovery learning sebesar 17,166. Adapun, setelah menggunakan metode discovery learning, nilai rata-rata posttest siswa menjadi 89,583 . Hasil penelitian menunjukkan bahwa kemampuan siswa dalam menulis kalimat Bahasa Jepang mengalami peningkatan yang signifikan sehingga dapat disimpulkan bahwa metode pembelajaran discovery learning dalam keterampilan menulis kalimat $\mathrm{Ba}-$ hasa Jepang terbukti sangat efektif dan memiliki konstribusi yang besar dalam meningkatkan hasil belajar siswa. 


\section{DAFTAR PUSTAKA}

Akanbi, A., \& Kolawole, C. (2014). Effects of Guided-Discovey and Self-Learning Strategies on Senior Secondary School Student's Achievement in Biology. Journal of Education and Leadership Development, 6(1), 19-42.

Arikunto, S. (2006). Prosedur Penelitian Suatu Pendekatan Praktik Edisi Revisi VI. Jakarta: Rineka Cipta.

Balim, A. G. (2009). The Effects of Discovery Learning on Students Success and Inquiry Learning Skills. Eurasian Journal of Educational Research, 9(35), 1-20.

Danasasmita, W. (2009). Metodologi Pembelajaran Bahasa Jepang. Bandung: Rizqi Press.

Farhatani, I. (2014). Peningkatan Kompetensi Mata Pelajaran Dasar dan Pengukuran Listrik Siswa Kelas X Program Keahlian Teknik Instalasi Tenaga Listrik di SMK Muhammadiyah 1 Klaten Utara dengan Metode Discovery Learning (Skripsi). Yogyakarta: Universitas Negeri Yogyakarta.

Huurun'ien, K. I., Efendi, A., \& Tamrin, A. G. (2017). Efektivitas Penggunaan E-Learning Berbasis Schoology dengan Menggunakan Model Discovery Learning terhadap Prestasi Belajar Siswa pada Mata Pelajaran Sistem Komputer Kelas X Multimedia SMK Negeri 6 Surakarta pada Tahun Pelajaran 2015/2016. Jurnal Ilmiah Pendidikan Teknik Kejuruan, 10(2), 36-46.

Illahi, M. T. (2012). Pembelajaran Discovery Strategy dan Mental Vocational Skill. Jogjakarta: Diva Press.

Rahman, R., \& Maarif, S. (2014). Pengaruh Penggunaan Metode Discovery Learning terhadap Kemampuan Anologi Matematis Siswa SMK Al-Ikhsan Pamarican Kabupaten Ciamis Jawa Barat. Jurnal Ilmiah Program Studi Matematika STKIP Siliwangi Bandung, 3(1), 33-58.

Setiyowati, P., \& Panggayuh, V. (2019). Pengaruh Model Pembelajaran Discovery Learning Menggunakan Video Scribe Sparkol terhadap Hasil Belajar SMK Perwari Tulungagung Kelas X Tahun Ajaran 2017/2018. Jurnal of Education and Information Communication Technology, 3(1), 12-21.

Sudjianto \& Dahidi, A. (2004) Pengantar Linguistik Bahasa Jepang. Jakarta: KBI.

Suminar, S. O., \& Meilani, R. I. (2016). Pengaruh Model Pembelajaran Discovery Learning dan Problem Based Learning terhadap Prestasi Belajar Peserta Didik. Jurnal Pendidikan Manajemen Perkantoran, 1(1), 80-89.

Tran, T., Nguyen, N. G., Bui, M. D., \& Phan, A. H. (2014). Discovery Learning with the Help of the GeoGebra Dynamic Geometry Software. International Journal of Learning, Teaching and Educational Research, 7(1), 44-57.

Waterman, S. (2013). The Effects of Discovery Learning: The Effects of Brainscape's Confidence-Based Repition on Two Adults' Performance on Knowledge-Based Quizzes (Master's Thesis). New York: State University of New York.

Wibowo, W. (2001). Manajemen Bahasa. Jakarta: Gramedia.

Yang, F. E., Liao, C. C., Ching, E., Chang, T., \& Chan, T. W. (2010). The Effectiveness of Inductive Discovery Learning in 1: 1 Mathematics Classroom. Proceedings of the 18th International Conference on Computers in Education, 743-747. 